Original Article

\title{
The present status, distribution, demography, and diet of the Dahl's Jird
}

\author{
Status atual, distribuição, demografia e dieta do Jird de Dahl \\ S.. Bulut ${ }^{2 *}$ \\ ${ }^{a}$ Hitit University, Department of Molecular Biology and Genetics, Çorum, Turkey
}

\begin{abstract}
Meriones dahli (Shidlovsky, 1962) was previously accepted to be a subspecies of M. meridianus (Pallas, 1773). However, it was later suggested that they are geographically isolated from each other. Although hybridological studies and differences in certain external characteristics support the idea that M. dahli is a separate species, there are still doubts on its species status, and the exact range of its distribution is not known. In this paper, we provide some taxonomic information about the species, and compare these with the information given in previous studies. We argue that some differences exist among Armenian population regarding external measurements. Recent studies indicate that $M$. dahli is currently only distributed in Turkey, as an endemic mammal species. We provide predictions about the distribution of $M$. dahli, and report the estimated population size to its maximum value. Food preference studies for this species, conducted under laboratory conditions, are also introduced for the first time. We discuss the ecological data obtained from field studies, and emphasize that the habitat of M. dahli is about to disappear. Consequently, the protection status of this species should urgently be changed to the CR category and conservation studies must be carried out immediately.
\end{abstract}

Keywords: Meriones dahli, population status, demography, feeding biology, distribution.

\begin{abstract}
Resumo
Meriones dahli (Shidlovsky, 1962) foi previamente aceito como uma subespécie de M. meridianus (Pallas, 1773). No entanto, mais tarde, foi sugerido que eles estão geograficamente isolados um do outro. Embora estudos hibridológicos e diferenças em certas características externas apoiem a ideia de que $M$. dahli é uma espécie separada, ainda há dúvidas sobre o status de sua espécie, e a extensão exata de sua distribuição não é conhecida. Neste artigo, fornecemos algumas informações taxonômicas sobre as espécies e as comparamos com as informações fornecidas em estudos anteriores. Argumentamos que existem algumas diferenças entre a espécie armênia em relação às medidas externas. Estudos recentes indicam que M. dahli está atualmente distribuído apenas na Turquia como uma espécie endêmica de mamífero. Fornecemos previsões sobre a distribuição de $M$. dahli e relatamos o tamanho estimado da população em seu valor máximo. Estudos de preferência alimentar para essa espécie, conduzidos em condições de laboratório, também são introduzidos pela primeira vez. Discutimos sobre os dados ecológicos obtidos em estudos de campo e enfatizamos que o habitat de $M$. dahli está prestes a desaparecer. Consequentemente, o status de proteção dessa espécie deve ser alterado com urgência para a categoria $\mathrm{CR}$, e estudos de conservação devem ser realizados imediatamente.
\end{abstract}

Palavras-chave: Meriones dahli, status populacional, demografia, biologia alimentar, distribuição.

\section{Introduction}

The genus Meriones (Illiger, 1811) is among the members of gerbils. Gerbils have a dominant distribution in the Palearctic, and can thrive in different habitats including clay and sandy deserts, low plains, cultivated areas, grasslands, mountain valleys, and slopes (Ashrafzadeh et al., 2019). They can adapt to a wide range of temperature and humidity conditions, from extremely dry and hot to dry and cold (Yiğit et al., 2006). Members of this genus display several similar morphological, behavioural and ecological characteristics; and their distribution can be sympatric, allopatric, parapatric, or stasipatric (Darvish, 2011).

The Dahl's Jird (Meriones dahli Shidlovsky, 1962) is a member of the genus Meriones. Until recently, it was considered a subspecies of M. meridianus (Pallas, 1773). Species independence was substantiated by hybridological analysis (Dyatlov and Avanyan, 1987), as well as the analyses on the karyotype structure of various subspecies of midday gerbil (Korobitsyna, Kartavtseva, 1984, 1986, 1988). Yiğit et al. (1997, 1998) identified the gerbil

*e-mail: safakbulut@hitit.edu.tr

Received: May 10, 2020 - Accepted: June 30, 2020

This is an Open Access article distributed under the terms of the Creative Commons Attribution License, which permits unrestricted use, distribution, and reproduction in any medium, provided the original work is properly cited. 
specimens collected from Turkey as $M$. meridianus due to their geographical proximity, dorsal fur colour, and biometric characteristics. However, Yiǧit et al. (2006) were later identified as Meriones dahli.

Turkey is home to 151 mammalian species (Kryštufek et al., 2009; Yiğit et al., 2006). Among these mammals, six are endemic to Turkey, and Meriones dahli lives only in a very narrow zone in the steppic mountain slopes in Iğdır and adjacent parts of Armenia (Ambarli et al., 2016). According to IUCN, M. dahli is the only rodent species listed in the endangered "EN" category in Turkey (Kefelioğlu et al., 2008). Although previously identified from also Armenia and Nakhichevan, M. dahli now probably only live in Turkey (Sahakyan et al., 2008), and is a local endemic species for Turkey, living in a limited area within the Aralık district near Mount Ağrı (in Iğdır province). It prefers shrubs and sandy areas.

Dahl's Jird has grey tones on its dorsal fur, and its abdominal fur is different from the other members of the genus Meriones, which is the typical genus of the subfamily Gerbillinae Gray, 1825. In addition to several characteristics common for the genus, the tail is entirely hairy, with the tip usually having a black tuft. The feet have yellow-reddish fur. The feet, besides being used for movement on loose sand, possibly aid in digging as well (Papanyan, 1971). The dimensions and structure of its skull morphology show similarities to M. meridianus (Nanova, 2014). Tympanic bullae are of medium size, and the bony tube of the ear canal touches the zygomatic arch (Pavlinov et al., 1990). The karyotype has a diploid set of 50 chromosomes, the number of shoulders is 78 (Korobitsyna and Kartavtseva, 1984; Baydemir et al., 2011).

This endemic small-sized jird was listed in the Red Books of the USSR and the Armenian SSR. The Soviet Socialist Republic created a 200-hectare Gorovansky Sands reserve to protect flora and fauna of this region, which was also inhabited by the Dahl's Jird. In the 60s, the total distribution area of Dahl's Jird was estimated to be less than 300 hectares (Adamyan et al., 1976). In the 70-80s, its dispersal range decreased sharply. The estimations of Dyatlov and Avanyan (1987) suggested that the absolute population of Dahl's Jird was within a range of 500 to 6,000 individuals during that period. According to Papanyan (1966), who conducted the most important and comprehensive study on the ecology of this species since the late 1950s, the average long-term abundance of Dahl's Jird on loosely fixed sands was 5.7\% in the spring (2.7-10.9\%) and $11.6 \%$ in autumn (3.6-17.2\%) per hundred trap-days. Adamyan et al. (1976), citing the maximum data of Papanyan, also noted a relatively low abundance for the species. However, Papanyan noted that the numbers were in the range of $5.2-8.7 \%$, and the data of Armenian specimens by the mid-70s no longer exceeded $6.1 \%$ per a hundred trap-days. From the 90 s to the present, the number of jirds averaged less than $1 \%$ per a hundred trap-days (Sahakyan, 2003), which indicates a steady decline in their numbers and a catastrophic situation for the population as a whole. The current state of $M$. dahli population is exceptionally vulnerable, and the species is possibly on the verge of extinction.
In this study, we focus on the ecological observations from our field studies conducted during 2017-2019. Based on the data of these three years, we present an update on the population dynamic of Meriones dahli, as well as its demographic structure, and studies on its conservation status. This is the first time that the distribution area and an estimated population density is given for M. dahli in Turkey. We also provide information on the food preferences of specimens caught in the field, as determined in studies carried out in the laboratory.

\section{Materials and Methods}

\subsection{Study area}

The study was conducted in the north of Mount Ağrı in

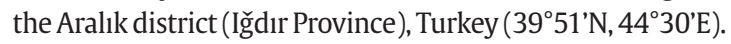
Aralık is the only district in Turkey which borders Nakhichevan, Armenia, and Iran. Mount Ağrı, Turkey's highest mountain has a peak of 5,136 $\mathrm{m}$ a.s.l. The northern parts of this mountain host a completely sandy desert habitat, where vegetation is rather scarce. Calligonum polygonoides L. ssp. comosum (L'Hér.) is the dominant plant species in the area, where our field studies were also carried out. The study area has no forests or dense woodlands, and is located in a region exposed to wind erosion. Some parts of the region are struggling with heavy erosion (Figure 1).

\subsection{Data collection}

Field studies were carried out between 2017 and 2019. M. dahli specimens were collected in August 2019.

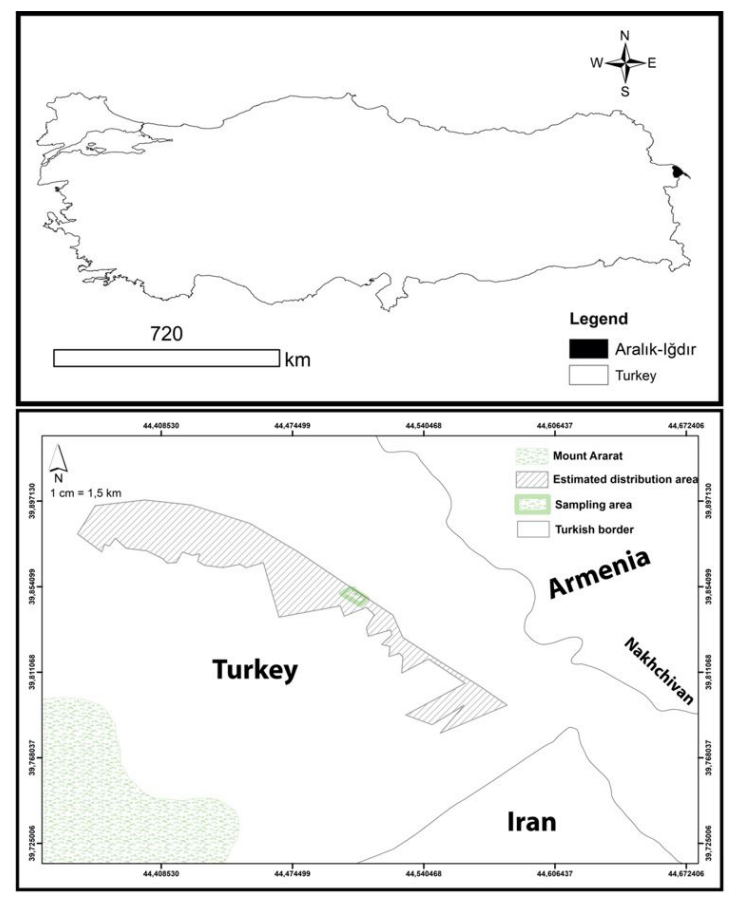

Figure 1. Distribution map of M. dahli in Turkey. 
The study was authorized by the Animal Ethics Committee at Niğde Ömer Halisdemir University. All specimens were collected by the Sherman trap, a live-capture trap widely used for small mammals (Foster and Gaines, 1991; Blaustein et al., 1996). Specimens captured in traps were moved directly to the laboratory cages laid with sawdust, where they were fed under uncontrolled laboratory conditions. A couple was placed in the same cage for the possibility of reproduction, but was later separated to individual cages upon observing no reproduction.

Sherman traps were randomly placed in order to estimate the population density. To reveal the habitat preferences of M. dahli, fieldwork was carried out in different regions, and burrow investigations were performed. The type of vegetation predominantly preferred by the species was determined. Besides, other vertebrate species sharing a habitat with the species were identified. Five external characters (total length, body length, tail length, hind foot length, and ear length) were measured (in $\mathrm{mm}$ ), and the body weights of collected specimens were recorded. The largest claw was included in the hind foot length, and other measurements were taken according to Harrison and Bates (1991). Body length was measured as the total length of the head and body, excluding the tail length.

Live specimens were put into cages $(60 \times 60 \times 60 \mathrm{~cm})$, and transferred to the laboratory. Skins and skulls of dead specimens were deposited in Hitit University's Department of Molecular Biology and Genetics, Faculty of Science and Arts.

\subsection{Diet analysis}

The study on dietary preferences was conducted in March 2020, based on both field and laboratory observations. In the field, both dead and alive specimens were collected by using Sherman traps. Laboratory studies were conducted on one adult male and four adult females caught in August 2019, which were transferred to individual cages $(61 \times 40 \times 33 \mathrm{~cm})$. Each cage had a nesting box, nesting materials, food, and water. The food intake of specimens was determined daily in the same day-time. Sunflower seeds, walnuts, grass, hazelnuts, peanuts, and wheat were given together to each specimen at the same time every day. All of the food items were weighed by sensitive scales $(0.01 \mathrm{~g})$ before being processed. The next day, at the same time, the remaining food was first cleaned off the cages together with all cage shavings, then separated from the shavings, and weighed. Water was always available in all enclosures, and was measured at the same time every day.

\section{Results}

\subsection{Population dynamics}

To reveal the population status of $M$. dahli, which had a sharp decline due to the rapid destruction and fragmentation of its habitats, marc-recapture studies were initiated in May 2017. We started by using 100 Sherman traps at $10 \mathrm{~m}$ intervals daily, intended for mark-recapture studies for three days every month. However, one adult female specimen was found dead in the trap on May 16, 2017. Therefore, we started an active/passive burrow count, and tried to determine an estimated population density. In June 2017, 30 burrows were located, and the mark-recapture studies were carried out only at the burrow exits. On June 19, 2017, one adult male, one adult female, and a juvenile individual were sampled. The field study performed in August 2017 resulted in no captured specimens. A total of 46 active/ passive burrows were counted in the field studies during 2018, but no sampling was carried out. On 21 August 2019, 40 burrows were counted, and all of them were trapped. A total of 7 individuals, consisting of 6 adult females and one juvenile were caught, and the external characters of 11 adult specimens were measured (Table 1 ).

It has been determined that this species is strictly psammophile. Habitats in Turkey, 830-930 meters above the sea level, are mostly hilly and strongly associated with loose sand. The burrows were always in areas where C. polygonoides was found. According to the data of August 2019, 40 active/passive burrows were determined during transect studies in an area of 50 hectares, where the burrows were the densest. Approximately half of the burrows were found to be active and there was a probability of 20 individuals in a total area of 50 hectares. According to the model created by taking into account the altitude data and the areas where $C$. polygonoides were is located, the total distribution area of $M$. dahli was calculated as 4,000 hectares. As a result, there can be a maximum of 1,600 individuals in the estimated possible distribution areas (Figure 2).

\subsection{Ecological aspects}

All of the Dahl's Jird burrows were located on sandy mounds, on which overgrown clumps of $C$. polygonoides were present. Most burrows had a simple structure and were located at shallow depth from the soil surface. These burrows had a single entrance hole with a mean width of $6 \times 9 \mathrm{~cm}$, often without any extensions.

Such simple burrows with usually a single entrance were observed to be used by the Dahl's Jird as temporary shelters. One of the Dahl's Jird burrows were dug during our field studies. It was constructed in a more sophisticated fashion, with wintering and nesting holes to spend the winter in. The total length of the burrow was $5 \mathrm{~m}$, and it had three entrances. The nesting chamber was $20 \times 25 \mathrm{~cm}$ in size, located at a depth of $1.4 \mathrm{~m}$ (Figure 3).

Table 1. Measurements of external characters of adult M. dahli specimens (in $\mathrm{mm}$ ).

\begin{tabular}{lcccc}
\hline \multicolumn{1}{c}{ Characters } & n & Mean & Range & SD \\
\hline Total length & 11 & 245.6 & $229-264$ & 9.95 \\
Body length & 11 & 115.5 & $94-131$ & 11.29 \\
Tail length & 11 & 128.4 & $112-136$ & 7.03 \\
Hind foot length & 11 & 32.9 & $31-36$ & 1.70 \\
Ear length & 11 & 16.3 & $15-18$ & 0.90 \\
Weight (g) & 11 & 67.5 & $52-95$ & 12.79 \\
\hline
\end{tabular}


Vulpes vulpes Linnaeus, 1758 was found as the mammalian predator of $M$. dahli throughout its possible distribution area. We took records of three diurnal raptors (Falco tinnunculus Linnaeus, 1758, Buteo rufinus (Cretzschmar, 1827), and Circus macrourus (Gmelin, 1770)) and two nocturnal raptors (Tyto alba (Scopoli, 1769) and Athene noctua (Scopoli, 1769)) in the region. The only predator reptile was a Macrovipera lebetina (Linnaeus, 1758) found in a M. dahli burrow. The only other rodent species in their habitat was Mus macedonicus Petrov and Ruzic, 1983. In the sampling studies carried out at altitudes of $1000 \mathrm{~m}$ and above, a low population of Meriones tristrami Thomas, 1892 was found. Still it was observed that its ecological niche did not overlap with that of M. dahli. On the other

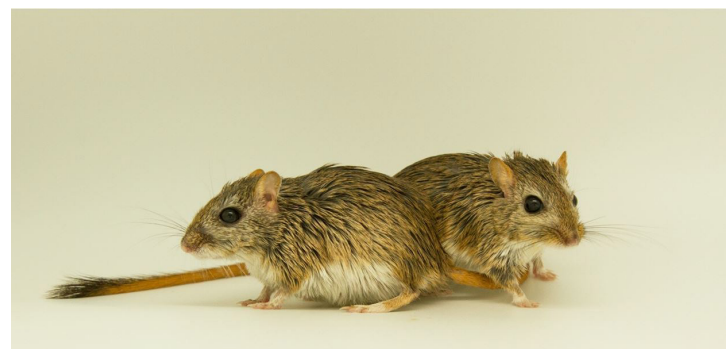

Figure 2. Meriones dahli specimens sampled from Aralık (Turkey) Photograph by Şafak Bulut. hand, Meriones vinogradovi Heptner, 1931 was sampled in more humid and grassy areas on the southern parts of Mount Ağrı.

The juvenile caught on June 19 was about a month old, indicating that it must have been born in mid-May, and the mating of its parents must have occurred in late April. Another juvenile caught on August 21, 2019 was also about one month old. These two records revealed that M. dahli gives birth twice a year, once in late April and once in July.

\subsection{Diet analysis}

Four adult M. dahli females kept in separate cages were offered different food varieties (sunflower seeds, walnuts, grass, hazelnuts, peanuts, wheat) for 4 weeks. Specimens showed no direct preference for food items when they were provided. We observed that the specimens took all the food items to the nests in their cages as soon as they were given, but did not eat all of them. The only food item eaten in all days was grass, and some of it was used as nest material. Some days, no other food items were eaten at all. We also observed that they separated the sunflower seeds from their shells. Water was always provided, and measured every day. It was estimated that the specimens drank an average of $1.8 \mathrm{~mL}$ of water daily, and consumed approximately $9.5 \mathrm{~g}$ of food every day (Table 2). In the field surveys, seeds of $C$. polygonoides were observed in front of the burrows.

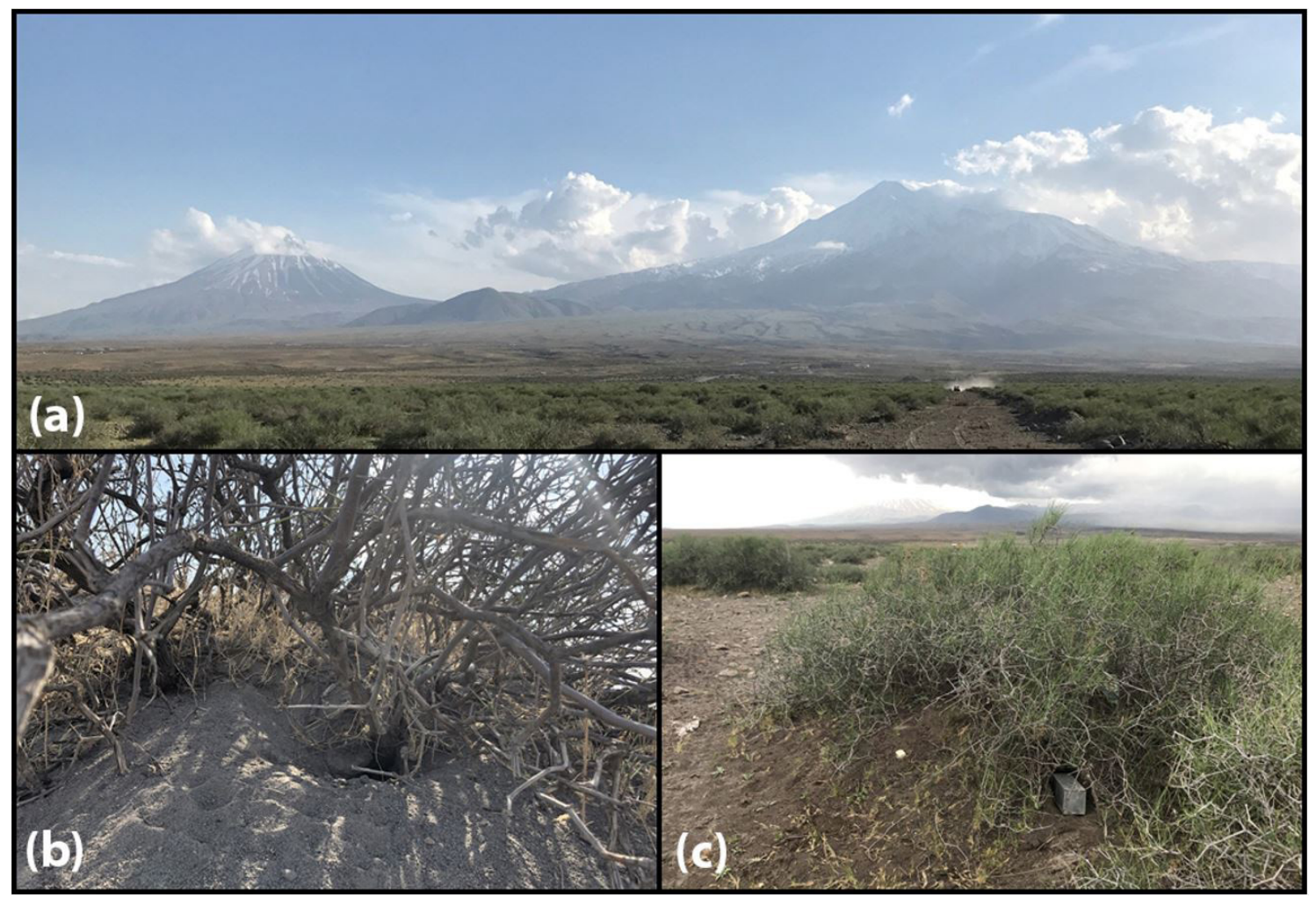

Figure 3. (a) Habitat; (b) burrow structure; and (c) burrow positioning of M. dahli in the Aralık District (Iğdır-Turkey). 
Table 2. Daily average values of food consumption of four female M. dahli specimens, also showing their diet preferences.

\begin{tabular}{cccccccc}
\hline Sample Number & Sunflower Seeds & Walnut & Grass & Hazelnut & Peanut & Wheat & Daily Avg. \\
\hline 103 & 0.61 & 2.01 & 4.97 & 1.21 & 1.65 & 0.41 & 10.85 \\
104 & 0.62 & 0.81 & 3.60 & 1.66 & 0.92 & 0.41 & 8.01 \\
105 & 0.55 & 1.47 & 3.74 & 2.70 & 1.51 & 0.37 & 10.34 \\
106 & 0.76 & 1.39 & 4.69 & 0.83 & 0.83 & 0.53 & 9.03 \\
Total Avg. & 0.63 & 1.42 & 4.25 & 1.60 & 1.23 & 0.43 & 9.56 \\
\hline
\end{tabular}

\section{Discussion}

M. dahli was previously accepted as a subspecies of M. meridianus. However, Corbet (1978) suggested that they were geographically separated from each other. Later, $M$. dahli was considered to be a separate species as a result of hybridological studies (Dyatlov and Avanyan, 1987) and due to some of its characteristics that differ from M. meridianus (Pavlinov and Rossolimo, 1998). Besides the doubt on its species status, its exact distribution range was also not known (Sahakyan et al., 2009). However, the study by Sahakyan et al. (2009), which was carried out between 2006 and 2007, revealed that M. dahli was no longer present in Armenia as a result of its natural distribution areas being converted into agricultural lands. In our study, we observed that M. dahli burrows were located only in areas where $C$. polygonoides shrubs were found. Our findings showed that there is no other gerbil species sharing an ecological niche with the Dahl's Jird in Turkey. It seems that the habitat of M. dahli was destroyed in both Armenia and Nakhichevan. Consequently, we claim that this species currently lives only in Turkey.

Papanyan (1971) noted the following average values for specific external measurements of $M$. dahli: body weight $48.1 \mathrm{~g}$, body length $114.0 \mathrm{~mm}$, tail length $121.0 \mathrm{~mm}$, hind foot length $26.2 \mathrm{~mm}$, and ear length $15.1 \mathrm{~mm}$. Kryštufek et al. (2009) gave the same measurements from Armenian museum specimens on average as body weight $49.9 \mathrm{~g}$, body length $117.4 \mathrm{~mm}$, tail length $117.2 \mathrm{~mm}$, hind foot length $28.3 \mathrm{~mm}$, and ear length $14.0 \mathrm{~mm}$.

The average values found by Yiğit et al. (1997) for the same measurements were body weight 63.5 g., body length $123 \mathrm{~mm}$, tail length $123.5 \mathrm{~mm}$, hind foot length $28.3 \mathrm{~mm}$, and ear length $14.0 \mathrm{~mm}$. In this, based on the measurements of 11 adult specimens, our findings seem to be closer to the values given in Yiğit et al. (1997) (Table 1). However, significant differences can be seen between the measurements from Armenian and Turkish specimens. These differences emphasize that the species should be taxonomically reviewed.

In Armenia, all of the habitats were reported to be of the same type, and all the distribution range was confined to areas with sandy soil, and mainly to hill-like locations with loosely fixed sand at an altitude of 600 to 1000 meters above sea level (Adamyan et al., 1976). But, during the field surveys of this study, we found no burrows or individuals of $M$. dahli below $830 \mathrm{~m}$ and above $950 \mathrm{~m}$.
In Armenia, Dahl's Jird used to inhabit two largest sections of Gorovan (40-50 ha) and Sadarak (about 70-80 ha), corresponding to the southwestern foothills of the Urts and Validag mountains. In the 60s, the total distribution area of Dahl's Jird was estimated to be less than 300 hectares (Adamyan et al., 1976). The total population estimate was 500-6,000 globally (Dyatlov and Avanyan, 1987). Later, in 1990s, the population estimate dropped to 500-1,000 (Pavlinov and Rossolimo, 1998). According to more recent data, $M$. dahli was thought to be extinct in the region (Sahakyan et al., 2009). In this study, we calculated the area where individuals were observed the most frequently as 50 hectares. Upon comparing this area with other similar habitats, we estimated that the species distribution area could be up to 4,000 hectares. However, we did not find any burrows in the areas that were frequently planted to control soil erosion. Reasons such as sand extraction for the purpose of expanding the highway between Turkey and Nakhichevan, as well as overgrazing, waste deposits from the district, and extremely heavy truck traffic are rapidly reducing and destroying the distribution areas of $M$. dahli.

Dahl's Jird that was kept in captivity during the summer drank no more than $10 \mathrm{~mL}$ of water per day (Papanyan, 1966). In our findings, daily water consumption of specimens was measured as $1.8 \mathrm{~mL}$ on average. This study introduced the dietary preferences and nutritional behaviour of the species in laboratory conditions for the first time (Table 2).

Burrows are known to usually consist of one entrance that is about 5-6 cm wide, and are often without any extensions. According to Papanyan (1971), the total length of their burrows can reach $7 \mathrm{~m}$, and the number of entrances can be up to 4 or 5 . The Dahl's Jird burrows we found consisted of one entry that had a width of about $6 \times 9 \mathrm{~cm}$, and they generally had no extensions. However, unlike Papanyan's (1971) study, we found that the total length of burrows reached up to $5 \mathrm{~m}$, and the maximum number of entrances was 3. Adamyan et al. (1976) mentioned that the nesting chamber is usually $20 \times 25 \mathrm{~cm}$ in size, and located at a depth of $50 \mathrm{~cm}$ to $2 \mathrm{~m}$. In our study, the nesting chamber in the only burrow we dug was $20 \times 25 \mathrm{~cm}$ in size, and it was located at a depth of $1.4 \mathrm{~m}$.

A number of other species can be found on the sand and in the vicinity of the Dahl's Jird, including Meriones tristrami, Meriones vinogradovi, Cricetulus migratorius (Pallas, 1773), Mus musculus Linnaeus, 1758, Allactaga sp. 
(Özkurt et al., 2001), Nannospalax sp., Lepus europaeus Pallas, 1778, Martes foina (Erxleben, 1777), Mustela nivalis Linnaeus, 1766, Vulpes vulpes, Canis lupus Linnaeus, 1758, and Meles meles (Linnaeus, 1758) (Popov and Ilchenko, 2007). The closest contact was observed to be with other gerbils and the grey hamster. Gerbil burrows can also be used as shelters by some reptiles, particularly lizards, and are visited by snakes while hunting gerbils (Popov and Ilchenko, 2007). The only other rodent species we found in M. dahli's habitat was Mus macedonicus, which had a low population density. In their vicinity were Hemiechinus auratus (Gmelin, 1770), Lepus europaeus, Allactaga elater (Lichtenstein, 1825), A. williamsi Thomas, 1897, Meriones tristrami, Sus scrofa Linnaeus, 1758, and Vulpes vulpes. Raptors encountered in the area such as Falco tinnunculus, Buteo rufinus, Circus macrourus, Tyto alba, and Athene noctua were considered their predators. The most active predators were the Levantine viper, owls and red fox, whereas other species were either rare or caught gerbils by chance.

Molecular phylogeny studies are needed to eliminate the doubts on the relationship between $M$. meridianus and M. dahli, and to clarify the species status of M. dahli. We strongly believe that it is necessary to update the IUCN category of Dahl's Jird as Critically Endangered (CR). The disappearance of $M$. dahli populations in Armenia and Nakhichevan, possibly due to the destruction of its preferred habitats, is well enough a reason to develop an emergency conservation plan for the endangered population of this species in Turkey. We also recommend breeding programs to enhance the captive populations in zoos, so we may have the opportunity of introducing more individuals to their natural habitat.

\section{Acknowledgements}

This study was supported by Hitit University's Scientific Research Project numbered FEF19001.17.004. I would like to thank Prof. Dr. Ahmet Karataş and Kadir Ulusoy for his support in field studies, and Müjde Fistık for her assistance in laboratory studies. Legal permissions for this study were provided by The Turkish Ministry of Agriculture and Forestry, General Directorate of Nature Conservation and National Parks. We are especially thankful to Mete Türkoğlu, Director of Iğdır Provincial Directorate of Nature Conservation and National Parks. Also, thanks to Deniz Candaş for the help in translation and final editing of this paper.

\section{References}

ADAMYAN, A.O., TARASOV, M.E. and DANIELYAN, S.M., 1976. On the southern jird in Armenia. Issues of Extremely Dangerous Infections, vol. 5, pp. 23-25.

AMBARLI, D., ZEYDANLI, U.S., BALKIZ, Ö., ASLAN, S., KARAÇETIN, E., SֵÖZEN, M., ILGAZ, Ç., GÜRSOY ERGEN, A., LISE, Y., DEMIRBAŞ ÇAGLAYAN, S., WELCH, H.J., WELCH, G., TURAK, A.S., BILGIN, C.C., ÖZKIL, A. and VURAL, M., 2016. An overview of biodiversity and conservation status of steppes of the Anatolian Biogeographical Region. Biodiversity and Conservation, vol. 25, no. 12, pp. 24912519. http://dx.doi.org/10.1007/s10531-016-1172-0.
ASHRAFZADEH, M., MADJDZADEH, S., AZARPIRA, M. and SHAHI, T., 2019. Intraspecific variation within Meriones persicus (Rodentia: Gerbillinae) populations in south central of Iran. Journal of Wildlife and Biodiversity, vol. 3, no. 1, pp. 40-51. http://dx.doi. org/10.22120/jwb.2018.98610.1042.

BAYDEMIR, N.A., DEMIRBAŞ, Y., PAMUKOǦLU, N., ALBAYRAK, I. and YAĞCI, T., 2011. Karyotypic studies of Meriones dahli Shidlovsky, 1962 (Rodentia: Muridae) from Turkey. Caryologia, vol. 64, no. 2, pp. 179-183. http://dx.doi.org/10.1080/00087114.2002.10589781.

BLAUSTEIN, L., KOTLER, B.P. and NEVO, E., 1996. Rodent species diversity and microhabitat use along opposing slopes of Lower Nahal Oren, Mount Carmel, Israel. Israel Journal of Zoology, vol. 42, no. 4, pp. 327-333.

CORBET, G.B., 1978. The mammals of the Palaearctic region: a taxonomic review. London: British Museum (Natural History).

DARVISH, J., 2011. Morphological comparison of fourteen species of the genus Meriones Illiger, 1811 (Rodentia: Gerbillinae) from Asia and North Africa. Iranian Journal of Animal Biosystematics, vol. 7, no. 1, pp. 49-74.

DYATLOV, A.I. and AVANYAN, L.A., 1987. Justification of species rank for two subspecies of Southern Jird (Meriones, Rodentia, Cricetidae). Zoologicheskii Zhurnal, vol. 66, pp. 1069-1074.

FOSTER, J. and GAINES, M.S., 1991. The effects of a successional habitat mosaic on a small mammal community. Ecology, vol. 72, no. 4, pp. 1358-1373. http://dx.doi.org/10.2307/1941108.

HARRISON, D.L. and BATES, P.J.J., 1991. The mammals of Arabia. 2nd ed. Sevenoaks, Kent, UK: Harrison Zoological Museum Publication.

KEFELIOǦLU, H., YIǦIT, N. and KRYŠTUFEK, B., 2008. Meriones dahli. In: INTERNATIONAL UNION FOR CONSERVATION OF NATURE AND NATURAL RESOURCES - IUCN. The IUCN Red List of Threatened Species 2008:e.T13162A3415328. Cambridge: IUCN. https://dx.doi.org/10.2305/IUCN.UK.2008.RLTS. T13162A3415328.en.

KOROBITSYNA, K.V. and KARTAVTSEVA, I.V., 1984. Certain issues of evaluation of karyotype of the southern jirds of the subfamily Gerbillinae Alston, 1879 (Rodentia, Cricetidae). In: T.S. BEKASOVA, ed. Evolution research: macroevolution. Vladivostok: Far East Department of the USSR Academy of Sciences, pp. 113-139.

KOROBITSYNA, K.V. and KARTAVTSEVA, I.V. 1986. Variability of the karyotype of Meriones meridianus Pallas 1773. In: The 4th Congress of the All-Union Mammalogists Society, 1986, Moscow. Moscow: Nauka, vol. 1, p. 65.

KOROBITSYNA, K.V. and KARTAVTSEVA, I.V., 1988. Variability and evolution of the karyotype of jirds (Rodentia, Cricetidae, Gerbillinae). 1. Karyotype differentiation of the Southern Jirds (Meriones meridianus) of the fauna of the USSR. Zoologicheskii Zhurnal, vol. 67, pp. 1889-1899.

KRYŠTUFEK, B., VOHRALÍK, V. and JANŽEKOVIČ, F., 2009. Mammals of Turkey and Cyprus: Rodentia II: Cricetinae, Muridae, Spalacidae, Calomyscidae, Capromydae, Hystricidae, Castoridae. Izvor: Univerza na Primorskem, Znanstveno-raziskovalno središče, Založba Annales.

NANOVA, O., 2014. Geographical variation in the cranial measurements of the midday jird Meriones meridianus (Rodentia: Muridae) and its taxonomic implications. Journal of Zoological Systematics and Evolutionary Research, vol. 52, no. 1, pp. 75-85. http://dx.doi.org/10.1111/jzs.12032.

ÖZKURT, I., YIǦIT, N., ÇOLAK, E., SÖZEN, M. and VERIMLI, R., 2001. Observations on the reproduction biology of Meriones meridianus Pallas, 1773 (Mammalia: Rodentia) in Turkey. Zoology in the Middle East, vol. 23, no. 1, pp. 23-29. http://dx.doi.org/10.108 0/09397140.2001.10637864. 
PAPANYAN, S.B., 1966. On the ecology of the midday gerbil Meriones meridianus Dahli Schidl. in the Armenian SSR. Biologicheskii Zhurnal Armenii, vol. 19, no. 5, pp. 68-80.

PAPANYAN, S.B. 1971. Ecology of gerbils of the Armenian SSR. Yerevan: Cand. dis.

PAVLINOV, I.Y. and ROSSOLIMO, O.L. 1998. Taxonomy of the mammals of the USSR. Moscow: MSU Publishers.

PAVLINOV, I.Y., DUBROVSKY, Y.A., ROSSOLIMO, O.L. and POTAPOVA, E.G., 1990. Gerbils of the world. Moscow: Publishing House Nauka of Kazakh USSR.

POPOV, S.V. and ILCHENKO, O.G., 2007. The Saving of Meriones dahli (Shidlovski, 1962). First Steps of EAZA Project on Conservation of the Dahl's Jird. Moscow: Moscow Zoo.

SAHAKYAN, L.V., 2003 [viewed 10 May 2020]. Dahl's Jird [online]. In Russian. Available from: http://www.biodiversity.ru/programs/ rodent/species/meriones_dahli.html

SAHAKYAN, LV., FAIVUSH, G.M. and KALASHYAN, M.Y., 2009. On the status of populations of Meriones dahliShidlovski 1962. In: N.ZAZANASHVULI and D. MALLON, eds. Status and protection of globally threatened species in the caucasus. Tbilisi: CEPF, WWF, Contour Ltd., pp. 111-116.
SAHAKYAN, L.V., MANRIKIAN, M.G., FAIVUSH, G.M. and KALASHYAN, M.Y. 2008. Certain features of ecology of jirds in the Goravan Sands in recent years. In: Proceedings of the Yerevan International Conference, 2008, Yerevan. Yerevan: International Educational Academy, pp. 48-49. In Russian.

SHIDLOVSKY, M.V., 1962. Key to rodents of the Caucasus. Tbilisi: Metzniereba.

YIĞIT, N., ÇOLAK, E., SÖZEN, M. and KARATAŞ, A., 2006. Rodents of Türkiye. In: A. DEMIRSOY, ed. Türkiye kemiricileri. Ankara, Turkey: Meteksan.

YIǦIT, N., KIVANÇ, E. and ÇOLAK, E., 1997. Diagnostic characters and distribution of Meriones Illiger, 1811 species (Mammalia: Rodentia) in Turkey. Turkish Journal of Zoology, vol. 21, no. 4, pp. 361-374.

YIǦIT, N., KIVANÇ, E. and ÇOLAK, E., 1998. Contribution to taxonomy and karyology of Meriones meridianus (Pallas, 1773 ) and Meriones crassus Sundevall,1842 (Rodentia: Gerbillinae) from Turkey. Mammalian Biology, vol. 63, pp. 311-314. 